\title{
Increasing the Yield of Soluble Mustard Protein Isolate
}

\author{
L. Karina Lorenzo ${ }^{1} \&$ Levente L. Diosady ${ }^{1}$ \\ ${ }^{1}$ Food Engineering Group, Department of Chemical Engineering, University of Toronto, Toronto, Canada \\ Correspondence: Levente L. Diosady, Food Engineering Group, Department of Chemical Engineering, \\ University of Toronto, Toronto, Canada. Tel: 1-416-978-4137. E-mail: 1.diosady@utoronto.ca
}

Received: June 15, 2015 Accepted: September 23, 2015 Online Published: November 16, 2015

doi:10.5539/jfr.v4n6p124 URL: http://dx.doi.org/10.5539/jfr.v4n6p124

\begin{abstract}
The objective of this study was to investigate methods for improving the yield of acid soluble mustard protein isolate (SPI) by solubilizing isoelectrically precipitated protein isolate (PPI). The SPI is more valuable, as it can be used in unique food applications. Four treatments were tested in the acidic $\mathrm{pH}$ range: Alcalase hydrolysis; transglutaminase cross-linking; salting in with $\mathrm{NaCl}, \mathrm{Na}_{5} \mathrm{P}_{3} \mathrm{O}_{10}$, and $\left(\mathrm{NaPO}_{3}\right)_{6}$; and protective colloid formation with pectin. The effectiveness of each treatment was determined by measuring the increase in nitrogen solubility (AOCS-Ba11-65). Alcalase hydrolysis improved PPI solubility evenly in the 2.5-3.5 pH range, effectively eliminating the solubility minimum near the isoelectric point. At $\mathrm{pH} \mathrm{3}$, the hydrolysis treatment increased solubility from $\sim 20 \%$ to a maximum of $\sim 70 \%$ ( $0.04 \mathrm{~g}$ of enzyme preparation $/ \mathrm{g}$ PPI, $\left.2 \mathrm{~h}, \mathrm{pH} 8.5,50-55^{\circ} \mathrm{C}\right)$. Protein hydrolysis during isolate production could increase the yield of SPI from 0.16 to $0.75 \mathrm{~kg}$ per kilogram of mustard protein.
\end{abstract}

Keywords: Mustard protein isolate, protective colloids, enzymatic protein hydrolysis

\section{Introduction}

\subsection{Background}

During the past two decades, there has been increasing interest in developing nutritious soft drinks, both for improved health and athletic performance in the industrialized world and for providing nutritional supplements in the developing world. While soya has been the most widely used vegetable protein, soy protein isolates and concentrates are not acid soluble, making them unsuitable for making clear carbonated beverages. Concerns about soy allergens and genetically modified organisms (GMOs) also encourages search for an alternative. The Food Engineering Group at the University of Toronto has developed a process to extract protein isolates from mustard seeds (US Patent 6,905,713 (2005)) that have a well-balanced essential amino acid composition and are free of the allergens typically found in soybeans.

The process results in two protein isolates: precipitated protein isolate (PPI: $80-90 \mathrm{wt} \%$ protein, dry basis, Nx6.25) and an acid-soluble protein isolate (SPI: 90-100 wt\% protein, dry basis, Nx6.25) (Diosady \& Chen, 2007). While PPI behaves similarly to soy protein, and can substitute it in many applications, SPI has high nitrogen solubility ( $>90 \mathrm{wt} \%)$ at nearly all $\mathrm{pH}$ values, opening unique applications in carbonated and acidic beverages (Diosady \& Chen, 2007).

The yield of PPI is typically much higher than that of SPI (Diosady \& Chen, 2007). It would be economically beneficial if the yield of SPI could be increased by converting some or all of the PPI to SPI. Accordingly, the objective of this study was to develop methods for improving the yield of SPI by increasing PPI solubility in the acidic $\mathrm{pH}$ range (2 to 4.5$)$. Four solubility enhancing treatments were tested: enzymatic hydrolysis (Alcalase), enzymatic cross-linking (transglutaminase), the addition of solutes to "salt in" the protein (sodium chloride, sodium tripolyphosphate, and sodium hexametaphosphate), and the use of pectin, a stabilizing agent, to form a protective colloid around the PPI. The effectiveness of each treatment was characterized in terms of increased nitrogen solubility.

\subsection{Solution Modification}

Certain ions cause protein precipitation ("salting out") while others improve the solubility of a protein ("salting in") (Mizubiti, Biondo, Souza, da Silva, \& Ida, 2000). The theory behind these effects is still unclear. A number of ions, however, are classified empirically in the Hofmeister series based on their ability to "salt in" or "salt out" 
proteins. Ions that "salt in" protein are thought to do so by interacting with the charged groups on the surface of proteins and decreasing the electrostatic attraction between opposite charges of neighboring protein chains or molecules (Charalambous \& Doxastakis, 1989). It was therefore an attractive potential approach for us to investigate.

In general, the concentration at which neutral salts may increase the solubility of proteins is in the order of 0.5 to $1 \mathrm{M}$ (Snow, 2007). At concentrations greater than $1 \mathrm{M}$, the protein solubility decreases and may result in precipitation. This "salting out" arises from the competition between the protein and salt ions for water molecules for solvation. At high salt concentrations, most of the water molecules will preferentially bind to the salts, leaving the protein without enough water molecules for its own solvation. This causes protein-protein interactions to become stronger than the solvent-protein interactions, which leads to protein aggregation and, in some cases, precipitation (Cheftel, Cuq, \& Lorient, 1985; Ellinger, 1972).

The effects of sodium chloride $(\mathrm{NaCl})$, sodium tripolyphosphate (STPP; $\mathrm{Na}_{5} \mathrm{P}_{3} \mathrm{O}_{10}$ ), and sodium hexametaphosphate (SHMP; $\left.\left(\mathrm{NaPO}_{3}\right)_{6}\right)$ on mustard PPI solubility were tested because they have been shown in the literature to improve protein solubility. They are recognized as safe for human consumption, within specified limits, and are commonly used in various processed foods. One drawback, however, to the use of ionic salts in improving solubility is that the addition of these may impart an unpleasant flavour to the final food product. Below $0.5 \mathrm{wt} \%$ the added salt typically will not overpower the flavour of the product. Unfortunately, this is also the threshold at which some charged ions begin to have a solubility enhancing effect.

Another approach to solvent environment modification is to form a protective colloid around the surface of the PPI resulting in a stable protein dispersion. A protective colloid forms when lyophilic particles become adsorbed in a thick layer onto the surface of other particles, the "protected particles" (Buzagh, 1937). This results in the "protected particles" acquiring the properties of the lyophilic colloidal solution (Lam, Shen, Paulsen, \& Corredig, 2007).

Pectin is a commonly used lyophilic stabilizing agent. Mixing pectin with protein isolates in solution results in a homogenous dispersion which remains stable over long periods of time and which is resistant to heat-treatments (Lam et al., 2007; CP Kelco, 2004). In addition, pectin also contributes positively to flavour, and it can be used to control texture, viscosity, and mouthfeel in the final product (Lam et al., 2007; CP Kelco, 2004).

Pectin is a polysaccharide that is typically prepared from the peels of citrus fruits and apples (Lam et al., 2007; CP Kelco, 2006). Its functionality depends on its overall charge and its charge distribution on its chain. The overall charge of the pectin is negative in solutions of $\mathrm{pH}$ greater than 3.5. For this reason pectin is expected to help disperse mustard PPI at $\mathrm{pH}$ values between 3.8 and 4.2. In this $\mathrm{pH}$ range, the pectin will be negatively charged and the protein isolate will be very weakly positively charged (as this is close to the isoelectric point). This results in the attraction of the pectin to the protein, binding, and formation of a protective colloid on the protein's surface (Lam et al., 2007; CP Kelco, 2004). The negatively charged protein surface will repel neighbouring protein particles, resulting in a stable dispersion. Outside of the 3.8 to $4.2 \mathrm{pH}$ range, however, pectin may actually enhance protein precipitation.

\subsection{Protein Modification}

The protease chosen for this study was Alcalase (Substilisin Carlsberg, E.C. 3.4.21.14). Alcalase is a serine endopeptidase (a protease that contains serine in its active centre) which cleaves on the carboxyl side of hydrophobic amino acids (Walsh, Cleary, McCarthy, Murphy, \& FitzGerald, 2003). Proteases are typically used in the food industry to produce soluble hydrolyzates of animal and vegetable proteins and heat or solvent-denatured proteins (Cheftel et al., 1985; Walsh et al., 2003; O’Meara \& Munro, 1984). They improve the solubility of proteins by cleaving these into smaller, highly charged molecules with a greater surface area available for interaction with the solvent. Alcalase was chosen for the hydrolysis experiments because it is relatively inexpensive and has been shown to be one of the most effective proteolytic enzymes for solubilizing protein (O'Meara \& Munro, 1984). Moreover, it is widely used in the food industry, and its reaction conditions are less conducive to microbial growth than those of other enzymes.

The cross-linking enzyme used in this study was transglutaminase ( $\lambda$-glutamyltransferase, E.C. 2.3 .2 .13 , referred to as Tgase in this paper). Tgase modifies proteins by catalyzing the formation of a covalent bond between a $\lambda$-carboxyamide (from glutamine) and lysine and forms an $\varepsilon$-( $\lambda$-glutamyl) lysine cross-link (Walsh et al., 2003 ; Wartiovaara, 1999). In the food industry, Tgase is commonly used in the processing of dairy, seafood, meat, soy, and bakery products, and has been reported to reduce the bitterness of several types of protein hydrolyzates (including milk and gluten hydrolyzates) (Blinkovsky, Brown, Golightly, Byun, Mathiasen, Kofod, Fujii, \& Marumoto, 2002; Watanabe, Arai, Tanimoto, \& Seguro, 1992). 
Tgase is a cross-linking enzyme and therefore increases the molecular mass of proteins by stitching peptide chains together covalently. This is known to cause a decrease in solubility as it induces aggregation (Cheftel et al., 1985; Dixon \& Webb, 1979). Moreover, cross-linking the $\varepsilon$-amino groups of lysine residues usually results in decreased protein solubility (Cheftel et al., 1985) as it results in the linking of two polar amino acids (lysine and glutamine) thus eliminating their ability to interact with the solution environment. However, in 2003, Walsh et al. (2003) used enzymatic cross-linking to improve the solubility of hydrolyzed protein isolates. It was hypothesized that Tgase increases the protein's solubility by improving its interaction with water by increasing the exposure of the protein's hydrophilic groups to the solution environment (Walsh et al., 2003). Thus, the combined use of proteolysis with Tgase cross-linking was also explored in this study.

\section{Materials and Experimental Methods}

\subsection{Materials}

The protein products used for this study were yellow mustard PPI produced in a pilot-scale test in the RTech Laboratories (St. Paul, MN, USA). The enzymes used in these tests were: Alcalase ${ }^{\circledR}$ (E.C. 3.4.21.14; Subtilisin Carlsberg, also known as Subtilisin A; a serine protease from Bacillus licheniformis; enzyme activity equal to 2.67 Anson Units per gram of preparation; Product No. P4860, Sigma-Aldrich ${ }^{\mathrm{TM}}$, St. Louis, MO, USA) and transglutaminase (E.C. 2.3.2.13; Activa-TI powder containing calcium independent transglutaminase and maltodextrin; 100 units of enzyme activity per gram of powder; Ajinomoto Food Ingredients LLC, Chicago, IL, USA). The salts used in these experiments were: sodium hexametaphosphate $\left(\left(\mathrm{NaPO}_{3}\right)_{6}\right.$, analytical grade; $\mathrm{BDH}$ Chemicals Ltd., Poole, England), sodium chloride ( $\mathrm{NaCl}$, analytical grade; EMD ${ }^{\mathrm{TM}}$, Gibbstown, NJ, USA), and sodium tripolyphosphate (STPP; $\mathrm{Na}_{5} \mathrm{P}_{3} \mathrm{O}_{10}$, analytical grade; Sigma-Aldrich ${ }^{\mathrm{TM}}$, St. Louis, MO, USA). The pectin used was a sample received from CP Kelco (GENU ${ }^{\circ}$ Pectin Type YM-100-L; containing pectin standardized with sucrose; CP Kelco, San Diego, CA, USA).

The protein content of the precipitated mustard protein isolate was determined to be $81.5 \pm 2.40 \mathrm{wt} \%$ on oil and moisture-free basis. This result was consistent with previous work reported by our group. The PPI used in this work had a low protein content because the starting material was not completely de-oiled during pilot-scale test production.

\subsection{Solution Modification Treatments}

A set amount of a solute was added to the PPI solution during the dissolution stage of the Nitrogen Solubility Index determination procedure. For the pectin experiments, the pectin was first mixed with $200 \mathrm{ml}$ of distilled water, heated to $70^{\circ} \mathrm{C}$, blended, and then added to the PPI powder (as was recommended by CP Kelco (2004) and Lam et al. (2007)). The Nitrogen Solubility Index was then determined.

\subsection{Enzymatic Treatments}

The PPI was treated with Alcalase within the concentration range of 0.02 to $0.06 \mathrm{~g}$ of Alcalase preparation per $\mathrm{g}$ of PPI, at $50^{\circ} \mathrm{C}$ and $60^{\circ} \mathrm{C}$, for varying lengths of time $(0.5 \mathrm{~h}$ to $24 \mathrm{~h})$. The reactions were carried out at $\mathrm{pH} 8.5$, which is the optimum $\mathrm{pH}$ for Alcalase hydrolysis according to Novo Industri A/S (1978). The concentration of endopeptidases conventionally used in industry ranges from 0.001 to 0.08 Anson Units (AU) per g of system protein (this range is equivalent to $0.0008 \mathrm{AU}$ to $0.06 \mathrm{AU}$ of enzyme preparation per $\mathrm{g}$ of PPI) (Blinkovsky et al., 2002). The majority of the experiments in this section were conducted at an enzyme concentration of $0.04 \mathrm{~g}$ of enzyme per $g$ of PPI sample ( 0.1 Anson Units per $g$ of PPI) as it represents the maximum amount of Alcalase that would be acceptable for commercial use.

After enzymatic treatment, enzymes are typically deactivated by heating to temperatures in the range of 70 to $100^{\circ} \mathrm{C}$ (Walsh et al., 2003; Dixon \& Webb, 1979). However, denaturation by means of heat at these temperatures may cause a significant decrease in protein solubility (Cheftel et al., 1985; deMan, 1999). Since enzymes are active only over a very limited $\mathrm{pH}$ range, it was decided instead to deactivate the Alcalase by lowering the solution $\mathrm{pH}$ to 3.5 and cooling the solution in the refrigerator immediately after completing the treatment. This $\mathrm{pH}$ and temperature is well outside the enzyme's activity range (Blinkovsky et al., 2002; Dixon \& Webb, 1979). Care was taken to not subject the PPI solution to a $\mathrm{pH}>5$ again during the remainder of the experiment to avoid reactivating the enzyme. After the enzyme deactivation step, the solution was flash frozen with liquid nitrogen and lyophilized over a period of two to three days. The dry, treated protein was then manually pulverized with a mortar and pestle and its Nitrogen Solubility Index was determined.

The progress of the hydrolysis reaction was measured by calculating the degree of hydrolysis $(\% \mathrm{DH})$. This was done by potentiometric titration of the protons released during protein hydrolysis at the constant reaction $\mathrm{pH}$ of 8.5. The formula below was used to calculate the degrees of hydrolysis incurred by the PPI protein. According to 
Cheftel et al. (1985), the average $\mathrm{pK}$ of $\alpha$ amino groups varies from 7.7 at $25^{\circ} \mathrm{C}$ to 6.9 at $60^{\circ} \mathrm{C}$. Assuming that the pK value follows a linear relationship from $25^{\circ} \mathrm{C}$ to $60^{\circ} \mathrm{C}$, the $\mathrm{pK}$ value for this experiment (conducted at $\sim 55^{\circ} \mathrm{C}$ ) was calculated to be 7.0. This results in an alpha value of 0.97 .

$$
\% \mathrm{DH}=\frac{1}{\alpha} \times \frac{(\text { mol alkali added per } \mathrm{g} \text { of protein })}{(\text { mol of peptide bonds per g of protein })} \times 100 \%
$$

Where $\alpha$ is the average dissociation coefficient of alpha-amino groups:

$$
\alpha=\frac{10^{(\mathrm{pH}-\mathrm{pK})}}{\left(1+10^{(\mathrm{pH}-\mathrm{pK})}\right)}
$$

During the hydrolysis reaction, each cleaved peptide bond results in one neutral $\alpha$-amino group and one ionized carboxyl group. Therefore, each mole of $\mathrm{NaOH}$ required for maintaining the solution $\mathrm{pH}$ at a constant of 8.5 is equivalent to one mole of hydrolyzed peptide bonds. The cumulative moles of $\mathrm{NaOH}$ required were determined by measuring the cumulative $\mathrm{NaOH}$ volume used during the reaction.

According to Dixon and Webb (1979), the moles of peptide bonds per gram of protein can be estimated from the amino acid composition of the protein. The amino acid profile of our PPI was determined by the Toronto Hospital for Sick Children HSC Advanced Protein Technology Centre. The information from this amino acid profile was used to calculate the moles of peptides per gram PPI. by assuming that the number of amino acid residues present in the protein is equivalent to the number of peptide bonds in the protein. The calculated value of 0.00612 moles of peptides per gram PPI is in fact a minor overestimation as the terminal amino acid residues are counted into the final number.

The procedure used for the enzymatic hydrolysis experiments was also used for the cross-linking experiments. The reactions were carried out at $55^{\circ} \mathrm{C}$ and $\mathrm{pH} 6.5$, as recommended by Ajinomoto Food Ingredients LLC (2007).

\subsection{Analytical}

The Nitrogen Solubility Index (NSI) was determined using the standard AOCS Ba11-65 method with minor modifications. Briefly, a $5 \mathrm{~g}$ sample of PPI powder was mixed with $250 \mathrm{ml}$ of distilled water $(125 \mathrm{rpm}, 120 \mathrm{~min}$, $30^{\circ} \mathrm{C}$, at a constant $\mathrm{pH}$ ) and was then decanted, centrifuged (1,500 rpm, $\left.10 \mathrm{~min}\right)$, and filtered with glass wool. The final solution contains protein deemed to be soluble (5). The concentration of the protein for each prepared solution was then determined in triplicate (alongside one blank control) by the standard Kjeldahl method (AOCS Ba4d-90). The amount of moisture present in the protein samples was measured by drying (in triplicate) $10 \mathrm{~g}$ of the protein powder at $110^{\circ} \mathrm{C}$ for 24 hours, dividing the difference in mass by the original powder weight, and multiplying by $100 \%$.

\section{Results and Discussion}

\subsection{Protein Isolate Solubility}

Figure 1 represents the nitrogen solubility curve of the unmodified mustard PPI. Each point on the graph represents an average of three replicates. As with all experimental results from this point on, the error bars in the graph represent the standard deviation. In some graphs, the error bars are difficult to discern as some of the standard deviation values were small.

The $\mathrm{pH}$ affects the charge and electrostatic balance between protein molecules and between the protein and the solvent. At $\mathrm{pH}$ values higher than the isoelectric point (in the basic $\mathrm{pH}$ range), proteins carry a net negative surface charge; at $\mathrm{pH}$ values lower than the $\mathrm{pI}$ (in the acidic $\mathrm{pH}$ range), proteins carry a net positive surface charge. This results in an increase in protein solubility as the protein surface charge enables the protein to interact with the neighboring water molecules and protein chains carrying electrical charges of the same sign will repel each other and expand or dissociate, thus promoting dispersibility (Charalambous \& Doxastakis, 1989; Cheftel et al., 1985; Buzagh, 1937). Near the isoelectric point, the net surface charge of the protein approaches zero and solubility reaches a minimum (Charalambous \& Doxastakis, 1989). The nitrogen solubility minimum for the PPI was observed at $\mathrm{pH} 4$ to 4.5 , consistently with the precipitation $\mathrm{pH}$. Mustard contains an array of different proteins, each with its own pI. For this reason, only $50-75 \%$ of the protein can be precipitated at a single $\mathrm{pH}$. 


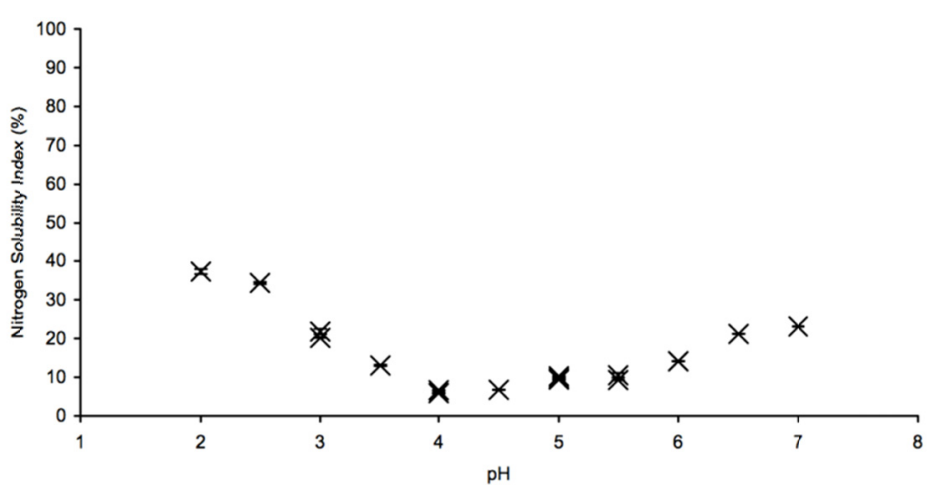

Figure 1. Unmodified RTech PPI nitrogen solubility as a function of solution $\mathrm{pH}$

\subsection{Solution Modification Treatments}

The effect of three sodium salts on the protein solubility was investigated. The results of these experiments are illustrated in Figure 2. The addition of $\leq 0.5 \mathrm{wt} \%$ sodium tripolyphosphate did not improve protein solubility at the isoelectric $\mathrm{pH}$, and actually decreased solubility at several $\mathrm{pH}$ values between 2 and 4.5. One trial run was performed with sodium hexametaphosphate, and it resulted in reduced protein solubility as well. Accordingly, both sodium hexametaphosphate and sodium tripolyphosphate appear unsuitable for improving mustard protein solubility at acidic $\mathrm{pH}$ values.
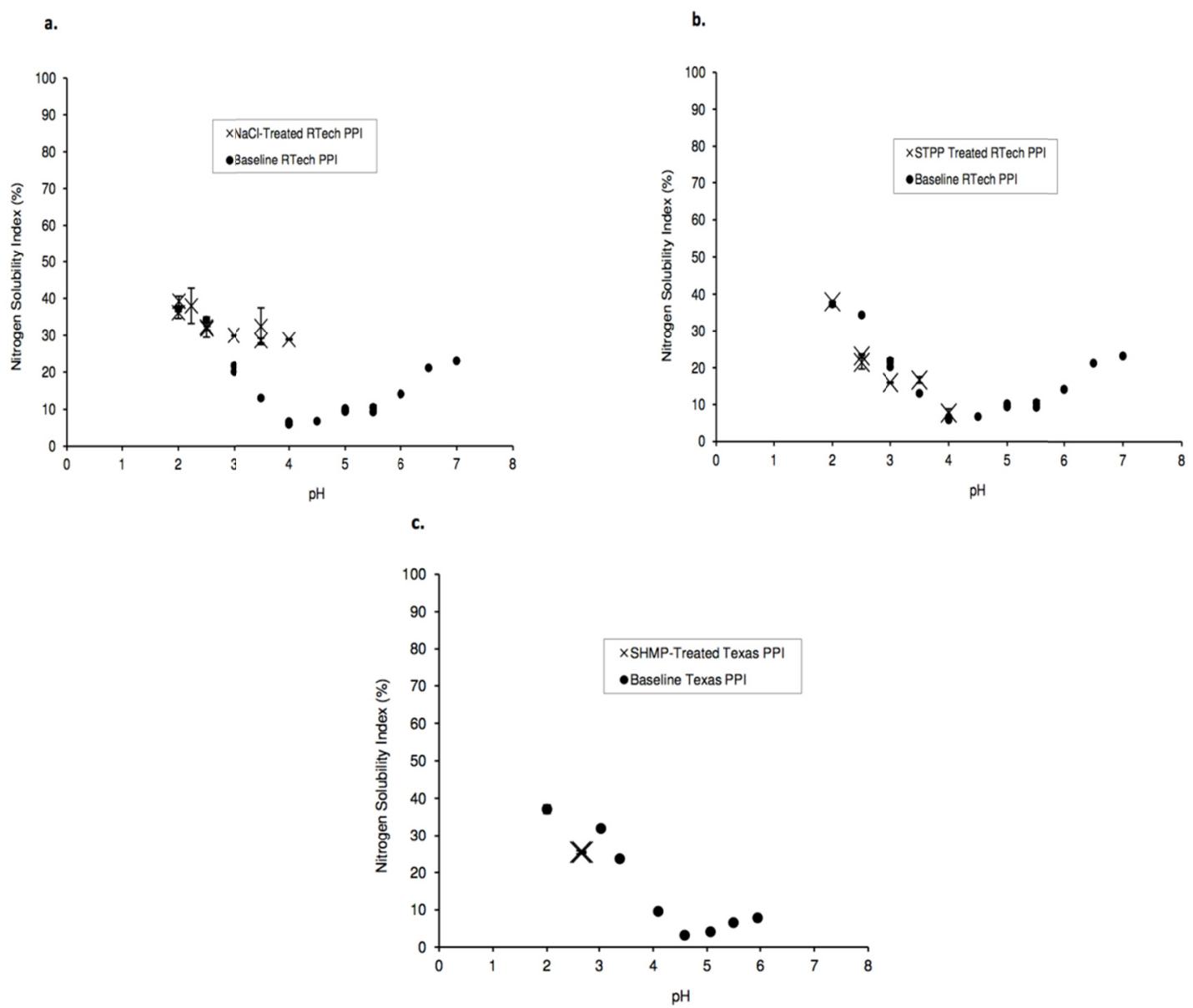

Figure 2. a. Solubility of $\mathrm{NaCl}$ treated RTech PPI $(0.46 \mathrm{~g}$ of NaCl / $\mathrm{g}$ of PPI or $0.7 \mathrm{~g}$ of NaCl / $\mathrm{g}$ of protein; resulting in a $1 \mathrm{wt} \%$ solution of $0.2 \mathrm{M} \mathrm{NaCl})$ b. Solubility of STPP treated RTech PPI $(0.008 \mathrm{~g}$ of STPP / $\mathrm{g}$ of PPI or $0.01 \mathrm{~g}$ of STPP / $\mathrm{g}$ of protein; resulting in a $0.02 \mathrm{wt} \%$ solution of $0.0005 \mathrm{M}$ STPP) c. Solubility of SHMP treated Texas PPI at $\mathrm{pH} 2.7$ (0.07 $\mathrm{g}$ of SHMP / $\mathrm{g}$ of PPI or $0.1 \mathrm{~g}$ of SHMP / $\mathrm{g}$ of protein; resulting in a $0.2 \mathrm{wt} \%$ solution of $0.0006 \mathrm{M}$ SHMP) 
$\mathrm{NaCl}$ improved PPI solubility near the isoelectric point and had no effect at lower $\mathrm{pH}$ values (Figure 2a). The maximum increase in solubility of PPI $(25 \%)$ was observed at the isoelectric point. Altemueller \& Guevara (2002) reported that $\sim 0.7 \mathrm{~g}$ of $\mathrm{NaCl} / \mathrm{g}$ of plant protein is the optimal amount of $\mathrm{NaCl}$ to be used to improve solubility. In this work, this same level was used which translated to $0.46 \mathrm{~g}$ of NaCl / $\mathrm{g}$ of PPI was used (as the protein content of RTech PPI is 69.12\%). However, this level (1 wt \% in solution) is highly impractical in terms of taste and residual sodium concentration. Therefore, another experiment was conducted to determine the minimum $\mathrm{NaCl}$ concentration required before its effects on PPI solubility were inconsequential. The $\mathrm{NaCl}$ concentrations used for this experiment were $10 \%, 25 \%, 50 \%$ and $70 \%$ of the amount used in the first experiment, corresponding to $0.04,0.12,0.23$ and $0.32 \mathrm{~g}$ of $\mathrm{NaCl}$ per $\mathrm{g}$ of PPI protein, respectively. These amounts translate to $\sim 0.1,0.2,0.5$ and $0.6 \mathrm{w} / \mathrm{v} \%$, respectively, in the treatment solution/suspension. After each treatment, the nitrogen solubility was determined at $\mathrm{pH} 3$. As expected, at low $\mathrm{NaCl}$ concentrations the salt addition appeared to have no effect on the PPI solubility. $\mathrm{NaCl}$ increased protein solubility by about $10 \%$ only at the higher levels of 0.66 and $0.92 \mathrm{w} / \mathrm{v} \%$. The test shows that $\mathrm{NaCl}$ could not be used to effectively improve solubility.

As recommended by CP Kelco (2004) (CP Kelco, 2004), pectin was used at pH 4 at a solution concentration of $1.5 \mathrm{w} / \mathrm{v} \%$, which has been deemed to be optimal. This treatment increased the solubility of PPI from $\sim 6 \%$ to $\sim 29 \%$. The pectin-protein system was stored in the refrigerator and remained in a stable colloidal dispersion for over one week. While the NSI was increased, this treatment resulted in an opaque, fine dispersion rather than the desired clear solution.

\subsection{Enzymatic Treatments}

The effect of the Alcalase treatment on the nitrogen solubility of the PPI is illustrated in Figure 3. With this treatment, PPI solubility more than tripled from $20 \%$ to a maximum of $75 \%$. The nitrogen solubility rose rapidly, reaching approximately $90 \%$ of the maximum value after 2 hours of treatment. There was minimal further increase in nitrogen solubility after 5 hours of reaction. The degree of hydrolysis also followed typical first order reaction kinetics with the degree of hydrolysis rising at an exponentially decreasing rate reaching the observed maximum value of $\sim 40 \%$. Interestingly, the degree of hydrolysis continued to rise slowly for all of the reaction runs, while after $5 \mathrm{~h}$, at higher degrees of hydrolysis, the nitrogen solubility did not increase further. The PPI solution became notably darker as the reaction time was increased, changing from a light tan colour to brown. As the solubility increased, the viscosity increased greatly, less solid was separated through centrifugation, and the solid protein residue could no longer be decanted.

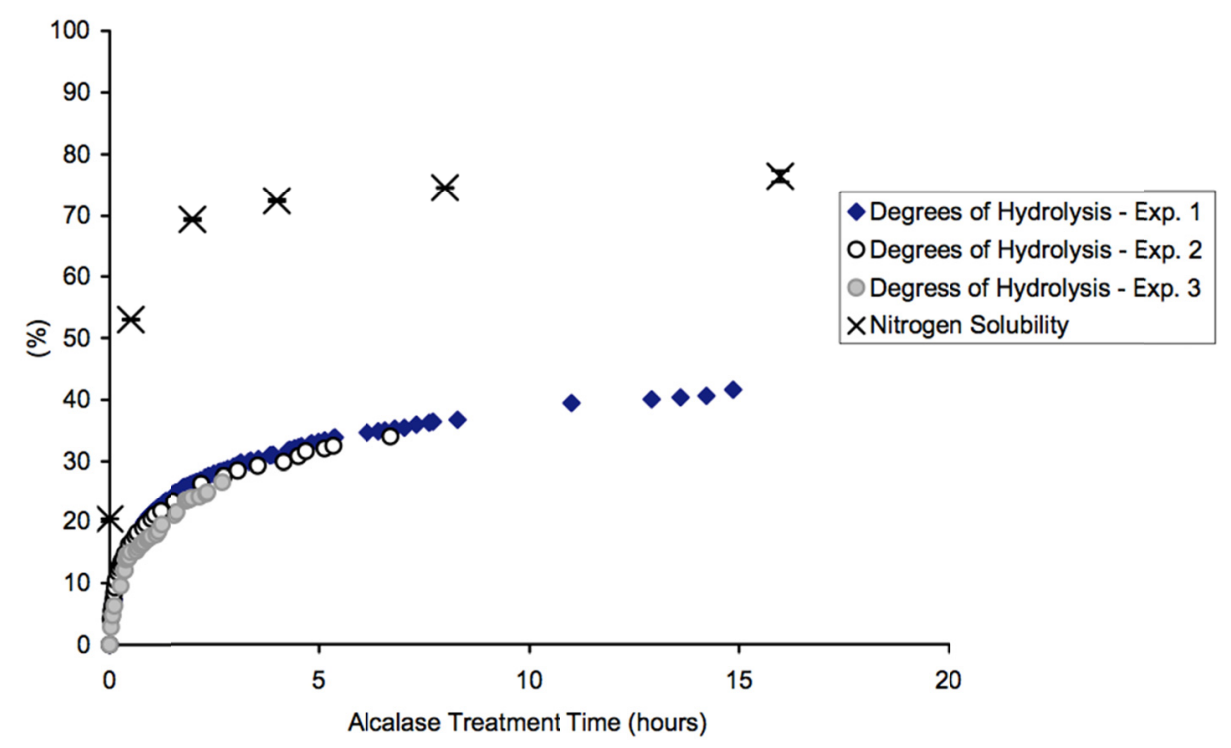

Figure 3. Nitrogen solubility ( $\mathrm{pH} 3$ ) and degrees of hydrolysis of Alcalase treated RTech PPI vs. treatment time (treatment constants: $50-55^{\circ} \mathrm{C}, 0.04 \mathrm{~g}$ of Alcalase preparation/g of PPI, $\mathrm{pH} 8.5$ )

As shown in Figure 4, hydrolysis significantly increased protein solubility in the $\mathrm{pH}$ 2.5-3.5 range. The solubilities were approximately constant, in contrast with the untreated PPI, which showed a rapidly decreasing 
protein solubility with increased $\mathrm{pH}$ in this range. The Alcalase hydrolysis treatment proved to be successful in increasing PPI nitrogen solubility from $35 \%$ to $65 \%$ at $\mathrm{pH} 2$ and from $15 \%$ to almost $70 \%$ at $\mathrm{pH} 3.5$, near the isoelectric point of the untreated protein.

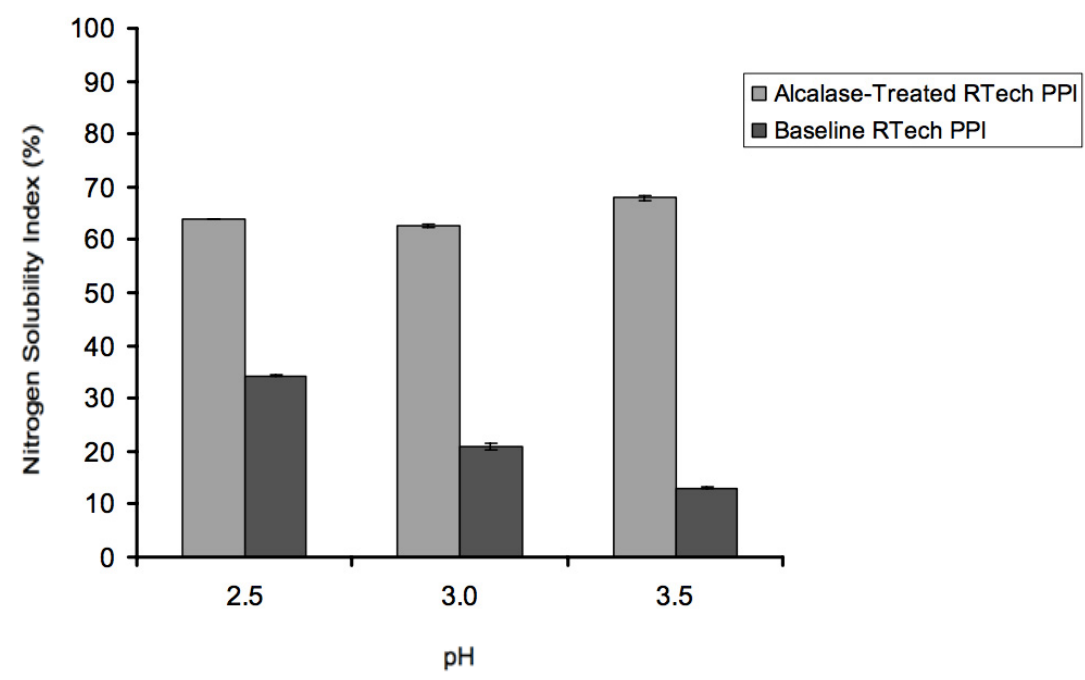

Figure 4. Solubility of Alcalase treated RTech PPI at a solution $\mathrm{pH}$ of 2.5, 3 and 3.5 (treatment constants: $50-55^{\circ} \mathrm{C}, 0.06 \mathrm{~g}$ of Alcalase preparation / $\mathrm{g}$ of PPI, $\mathrm{pH} 8.5,1 \mathrm{~h}$ )

The transglutaminase treatment decreased the solubility of PPI at $\mathrm{pH} 3$ by $\sim 5-10 \%$ over a span of concentrations ranging from 0.00001 to $0.1 \mathrm{~g}$ of Tgase / $\mathrm{g}$ isolate (reaction conditions: $55^{\circ} \mathrm{C}, 2.5 \mathrm{~h}, \mathrm{pH} 6.5$ ). This concentration range represents the acceptable range of concentrations for Tgase enzymes in industry (Ajinomoto Food Ingredients LLC, 2007). The Tgase-treated PPI was easier to pulverize and resulted in a finer powder. Consistently with the literature, the product was lighter in colour than both Alcalase-treated PPI and unmodified PPI.

To determine if Tgase had an effect on the solubility of Alcalase-hydrolyzed PPI, two more experiments were conducted. For each experiment, PPI that had been lyophilized after being hydrolyzed with Alcalase $(5 \mathrm{~h}, 0.04 \mathrm{~g}$ of Alcalase preparation / $\mathrm{g}$ PPI, $\left.50-55^{\circ} \mathrm{C}, 8.5\right)$ was treated with Tgase for several treatment times and concentrations. Again, the resulting solubility of each treated powder was determined at $\mathrm{pH} 3$.

Table 1. NSI at $\mathrm{pH} 3$ for Alcalase and Tgase treated RTech PPI for various Tgase treatment times (Tgase treatment conditions: $50-55^{\circ} \mathrm{C}, \mathrm{pH} 6.5,0.01 \mathrm{~g}$ of Tgase preparation / g protein; Alcalase treatment conditions: $5 \mathrm{~h}$, $0.04 \mathrm{~g}$ Alcalase preparation / $\mathrm{g}$ PPI, $\left.\mathrm{pH} 8.5,50-55^{\circ} \mathrm{C}\right)$

\begin{tabular}{cc}
\hline Treatment Time $(\mathrm{h})$ & Average N Solubility $(\%)$ \\
\hline 0 & $75.50 \pm 0.16$ \\
0.5 & $50.74 \pm 0.17$ \\
1 & $51.79 \pm 0.09$ \\
2 & $53.58 \pm 1.10$ \\
8 & $52.48 \pm 0.12$ \\
16 & $50.92 \pm 0.04$ \\
\hline
\end{tabular}

The amount of Tgase used for this first hydrolysis/cross-linking combination experiment was $0.1 \mathrm{~g}$ of Tgase preparation / $\mathrm{g}$ of system protein, which represents the maximum concentration that would be used in an industrial setting. These results also indicated a loss in solubility. The solubility of the control hovered at $\sim 75 \%$ while the solubility of Tgase-treated PPI was 20 to $25 \%$ lower. Interestingly, the Tgase decreases the solubility of the PPI to a minimum level after as little as 30 minutes of treatment time. After that time, it appears as though 
additional Tgase treatment has no effect (see Table 1). This may have been due to the inactivation of the enzyme at the reaction $\mathrm{pH}$ and temperature. Alternatively, the degree of substrate saturation of the enzyme may have fallen over time as the concentration of product increased. The second hydrolysis/cross-linking combination experiment consisted of treating Alcalase hydrolyzed PPI with Tgase at several concentrations (from 0.00001 to $0.1 \mathrm{~g}$ of Tgase preparation / $\mathrm{g}$ of system protein) for 2.5 hours (see Table 2). Again, the solubility of the treated PPI was 15 to $25 \%$ lower than the solubility of the control.

Table 2. NSI at $\mathrm{pH} 3$ for Alcalase and Tgase treated RTech PPI for various Tgase treatment concentrations (Tgase treatment conditions: $50-55^{\circ} \mathrm{C}, \mathrm{pH} 6.5,2.5 \mathrm{~h}$; Alcalase treatment conditions: $5 \mathrm{~h}, 0.04 \mathrm{~g}$ of Alcalase preparation / g PPI, $\mathrm{pH} 8.5,50-55^{\circ} \mathrm{C}$ )

\begin{tabular}{cc}
\hline $\begin{array}{c}\text { Tgase Concentration } \\
\text { (g Tgase / g system protein) }\end{array}$ & Average N Solubility (\%) \\
\hline 0 & $68.35 \pm 0.10$ \\
0.00001 & $54.24 \pm 0.05$ \\
0.0001 & $51.41 \pm 0.04$ \\
0.001 & $54.09 \pm 0.21$ \\
0.01 & $52.84 \pm 0.09$ \\
0.1 & $49.34 \pm 0.09$ \\
\hline
\end{tabular}

It is clear from the results that Tgase is not an effective method for improving the solubility of the PPI at this $\mathrm{pH}$, as it decreases the solubility of both unhydrolyzed and hydrolyzed PPI over a broad range of treatment concentrations and times. The final solubility of PPI that is treated with both Tgase and Alcalase is still higher than that of the unmodified PPI. Since Tgase improved the isolate's taste and colour, its use may still be justified in some cases.

\section{Conclusions}

The project demonstrated that solubility of isoelectrically precipitated mustard protein isolate (PPI) could be significantly increased by treatments acceptable to the food industry. The most promising treatment investigated in the study was Alcalase hydrolysis, which resulted in nitrogen solubility of $\sim 70 \%$ in the $\mathrm{pH}$ range of 2.5 to 3.5 . The results suggest that the current protein isolation process could be modified to include hydrolyzation of the PPI after it is recovered by the isoelectric precipitation, centrifugation, and washing steps. This wet cake could then be re-suspended and hydrolyzed. After treatment, the solubilized protein could be separated from the insoluble fraction by an additional centrifugation and washing step. The solution of the hydrolyzed PPI protein would then be mixed with the SPI solution and recovered after ultrafiltration, diafiltration, and drying. The insoluble fraction of the PPI would be dried and sold as PPI. This processing change would increase the yield of soluble protein isolate from $0.16 \mathrm{~kg}$ to $0.75 \mathrm{~kg}$ while decreasing the yield of less valuable PPI from $0.84 \mathrm{~kg}$ to $0.25 \mathrm{~kg}$, per kilogram of mustard protein. The treatment for increasing the yield of SPI could increase the value of the mustard protein isolates produced with the process by $\sim 30 \%$ to $120 \%$, and would provide a novel protein suitable for inclusion in acidic or carbonated beverages.

\section{Acknowledgements}

We would like to thank NSERC-CGS, OGS, and the Department of Chemical Engineering, University of Toronto for their financial support, and CP Kelco, Ajinomoto, and Hermann Laue Spice Company of Canada for providing the samples used in this study.

\section{References}

Agriculture and Agri-Food Canada. (2005). Canada's Mustard Seed Industry. Canada's Agriculture, Food and Beverage Industry. Retrieved April 14, 2008, from ats-sea.agr.gc.ca/supply/factsheets/3311_e.pdf

Ajinomoto Food Ingredients LLC. (2007). ACTIVA® General information - Transglutaminase basics. Printed information sheet.

Altemueller \& Guevara. (2002). Functional Food Ingredient. US Patent No. 09,795,717.

Blinkovsky, A., Brown, K., Golightly, E., Byun, T., Mathiasen, T. E., Kofod, L. V., ... Marumoto, C. (2002). U.S. 
Patent No. 6,465,209. Washington, DC: U.S. Patent and Trademark Office.

Buzagh. (1937). Colloid Systems. London: The Technical Press Ltd.

Charalambous, \& Doxastakis. (1989). Food Emulsifiers: Chemistry, Technology, Functional Properties, and Applications, New York: ElSevier.

Cheftel, Cuq, \& Lorient. (1985). Food Chemistry, $2^{\text {nd }}$ edn., New York: Marcel Dekker.

CP Kelco. (2004). Application Bulletin: Refreshing Dairy Beverages - GENU®: a key ingredient in stabilization of yoghurt drinks and juice-milk drinks. Printed product guide.

CP Kelco. (2006). Secrets of beverage properties uncovered. CP Kelco Techtalk, 3(5), 1-4.

deMan. (1999). Principles of Food Chemistry. A Chapman \& Hall Food Science Book. Gaithersburg, Maryland: Aspen Publishers, Inc.

Diosady, L. L., Xu, L., \& Chen, B. K. (2007). Production of high-quality protein isolates from oilseeds seeds. United States Patent Number 20070237877.

Dixon, \& Webb. (1979). Enzymes. New York: Academic Press.

Ellinger. (1972). Phosphates as Food Ingredients, CRC Press (Chemical Rubber Co): Cleveland, Ohio.

Lam, M., Shen, R., Paulsen, P., \& Corredig, M. (2007). Pectin stabilization of soy protein isolates at low pH. Food Research International, 40, 101-110.

Mizubuti, I. Y., Júnior, O. B., de Oliveira Souza, L. W., \& Ida, E. I. (2000). Response surface methodology for extraction optimization of pigeon pea protein. Food Chemistry, 70(2), 259-265.

Novo Industri A/S. (1978). Information Bulletin number 163-GB, Novo Industri A/S, Bagsvaerd, Denmark.

O'Meara, G. M., \& Munro, P. A. (1984). Selection of a proteolytic enzyme to solubilize lean beef tissue. Enzyme and Microbial Technology, 5, 181-185.

Smith, \& Jimmerson. (2005). Mustard Seed. Briefing, Montana State University: Agricultural Marketing Policy Centre.

Snow. (2007). Principles of Biochemistry I: Biomolecular Structure. Department of Chemistry \& Biochemistry, University of the Sciences in Philadelphia. Retrieved May 1, 2008, from tonga.usip.edu/jsnow/chem341/chapter5.pdf

Walsh, D. J., Cleary, D., McCarthy, E., Murphy, S., \& FitzGerald, R. J. (2003). Modification of the nitrogen solubility properties of soy protein isolate following proteolysis and transglutaminase cross-linking. Food Research International, 36, 677-683.

Wartiovaara. (1999). Coagulation Factor XIII (FXIII) and Vascular Endothelial Factors VEGF-C Produced by Platelets: From Clinical Findings to Molecular Characteristics. Departments of Clinical Chemistry and Biomedicine, University of Helsinki, Helsinki, academic dissertation.

Watanabe, M., Arai, S., Tanimoto, S., \& Seguro, K. (1992). Functional peptide obtained by partially hydrolysing foodstuff protein with protease and/or acid to give hydrolyzed peptide which is treated with transglutaminase. Japanese Patent No. JP1992-126039.

\section{Copyrights}

Copyright for this article is retained by the author(s), with first publication rights granted to the journal.

This is an open-access article distributed under the terms and conditions of the Creative Commons Attribution license (http://creativecommons.org/licenses/by/3.0/). 